\title{
Metabolic and Enzymatic Evaluation of Lentil (Lens culinaris M.) Seedlings under Drought Stress
}

\author{
Ajaya Eesha, Monalisa Kulshrestha, Poonam Choudhary, Amit Kumar ${ }^{1}$, A.K. Nag ${ }^{2}$
}

10.18805/IJARe.A-5884

\begin{abstract}
Background: In the agricultural context, drought is a period of deficient water conditions, resulting in negative effects on crop growth and yield. A continuous increase in global temperature, leading to warmer climatic conditions, is expected to further increase the severity and frequency of drought.

Methods: The experiments were carried out during 2018-2019 under laboratory conditions to study the effects of PEG-6000 on seedling growth in eight genotypes of lentil (Lens culinaris Medik.).

Result: Our research work evaluated the effect of PEG-6000 induced drought stress on metabolite and enzymatic activity of eight genotypes of lentil (Lens culinaris Medik.) (PL-4, L-4147, L-4594, L-4596 belonging to microsperma subspecies and K-75, L-4076, DPL-15, DPL-62 belonging to macrosperma subspecies). Drought stress significantly increased metabolite content i.e., protein, proline and carbohydrate and enzyme activity i.e., acid phosphatase, invertase in drought tolerant genotypes (PL-4, L-4594, DPL-15 and DPL-62) and reduced amount of these metabolites and enzymes was observed in drought susceptible genotypes (L-4147, L4596, K-75, L-4076).
\end{abstract}

Key words: Drought, Macrosperma, Microsperma, Polyethylene glycol (PEG-6000).

\section{INTRODUCTION}

Drought stress decreases both germination percentage and seedling growth in plants (Kaya et al. 2006). It is also dependent on the growth of plant and stress conditions. Short-term drought stress affects the plants, which ultimately leads to the decline in growth and yield (Muscolo et al., 2014). Drought stress induced crop yield loss is generally more prominent then other biotic and abiotic stresses, because severity and duration of drought stress are critical (Gul et al., 2020). Drought causes changes in nutrient acquisition and assimilation, water relations, photosynthesis, assimilates partitioning and enzyme functioning (Ayyaz et al., 2021; Xiong et al., 2020; Bano et al., 2021).

Lentil (Lens culinaris Medik) is amongst the oldest domesticated plants in the world. It is traditionally cultivated in the Mediterranean basin and originated from the near East and central Asia (Zohary, 1972). Lentil is grown in semiarid environment where unfavourable soil moisture at sowing conditions leads to an irregular seedling emergence, it negatively affects the establishment of a crop stand and a reduction in crop yield (Okcu et al., 2005). Lentil is economically important because its seeds are an important source of protein for the human beings and the entire plant is a valuable animal feed. Lentil yield can be increased with regular irrigation (Salehi et al., 2008). This can improve seed yield, seed size, biomass yield and harvest index (Khourgami et al., 2012). In annual plant species successful plant establishment largely depends on proper seed germination and seedling emergence (Forcella et al., 2000). Rapid and uniform seed germination ultimately leads to a successful crop establishment in semiarid areas and this is associated to the ability of seeds to germinate under low water
Department of Botany, S.S. Jain Subodh P.G. (Autonomous) College, Jaipur-302 004, Rajasthan, India.

${ }^{1}$ School of Life Sciences, Jaipur National University, Jaipur-302 004, Rajasthan, India.

${ }^{2}$ Rajasthan Agricultural Research Institute, Durgapura, Jaipur-302 004, Rajasthan, India.

Corresponding Author: Ajaya Eesha, Department of Botany, S.S. Jain Subodh P.G. (Autonomous) College, Jaipur-302 004, Rajasthan, India. Email: ajayaeasha@gmail.com

How to cite this article: Eesha, A., Kulshrestha, M. Choudhary, P., Kumar, A. and Nag, A.K. (2022). Metabolic and Enzymatic Evaluation of Lentil (Lens culinaris M.) Seedlings under Drought Stress. Indian Journal of Agricultural Research. DOI: 10.18805/IJARe.A-5884.

Submitted: 19-07-2021 Accepted: 17-12-2021 Online: 25-01-2022

availability. In such cases drought tolerance studies at the germination stage has specific importance (IPCC 2007). Drought can reduce the germination percentage (GP) and germination rate (GR) which ultimately leads to negative seedling growth (Abdellaoui et al., 2019). Polyethylene glycol (PEG) is a natural polymer molecular. Molecular weight of $P E G$ is 6000 . It is water-soluble and nonionic (Ranjbarfordoei et al., 2000). PEG 6000 mimics drought stress causing osmotic stress resulting in lowering of plant's water potential (Muscolo et al., 2014). Effect of PEG can be seen during seed germination and emergence of seedlings is also affected by PEG that directly affects development, root and shoot growth and even flowering and pod formation.

Water plays an important role in the hydrolytic breakdown of proteins, lipids and carbohydrates in the storage tissues of germinating seeds. Water is also involved 
in solubilisation and transportation of metabolites and in many enzymatic reactions (Biaecka and Ke²pczyn' ski, 2010). However, drought stress studies can be done under natural field conditions but sometimes it is difficult as rainfall can eliminate natural drought stress conditions. Now-a-days in vitro drought-screening methods are in progress to understand drought-resistance traits. These are also helpful in selection of drought-tolerant genotypes. Germination and seedling establishment stages are most sensitive stages to drought stress (Desclaux et al., 2000). Polyethylene glycol (PEG-6000) solutions have been effectively used to develop drought stress in lab conditions (Hohl and Schopfer, 1991).

The aim of research work is to evaluate the drought tolerant genotypes amongst the eight genotypes of $L$. culinaris Medik. under drought stress conditions by analysing some biochemical parameters.

\section{MATERIAS AND METHODS}

The experimental work was conducted during 2018-2019 at the Laboratory of Botany, S.S. Jain Subodh P.G. (Autonomous) College, Jaipur to study the effect of drought stress during early growth of genotypes of Lentil (Lens culinaris Medik.) under osmotic stress. The work involved eight genotypes of lentil (Lens culinaris Medik.) i.e., PL-4, L-4594, L-4147, L-4596, belonging to microsperma subspecies of lentil and K-75, L-4076, DPL-15, DPL-62 belonging to macrosperma subspecies. Genotypes used were procured from Indian Agricultural Research Institute, Pusa, New Delhi. Preparation of PEG-6000 solution was done by dissolving $15 \mathrm{gm}$ of PEG-6000 in $100 \mathrm{ml}$ of water.

For each genotype, the seeds were decontaminated with sodium hypochlorite solution (2\%) for $2 \mathrm{~min}$. The seeds were then rinsed with distilled water several times to remove any impurities on the seeds. The seeds were then germinated in petri dishes containing a layer of Wattman paper-soaked with distilled water and the seeds were germinated till seven days. Then the seeds were treated with PEG-6000 solution (15\%) up to 20 days, leaves from the seedlings were collected for the evaluation of drought tolerance based on various parameters. The experimental sets for the eight genotypes were replicated three times.

The biochemical responses (protein content, proline content and carbohydrate content) were observed in leaves of 20 days old seedling. Some of the enzyme (acid phosphatase, invertase and nitrate reductase enzymes) activities were also measured. Thus, the main objective of this research was to understand the biochemical mechanisms of adaptation to drought stress by lentil during the early seedling stages.

\section{Biochemical parameters: Metabolites}

Following metabolic parameters were studied in all eight lentil genotypes.

\section{Protein content}

Bradford's method (1976) was used for the estimation of soluble proteins.

\section{Total carbohydrate content}

Total carbohydrate content measurement was done by the method of Dubois et al. (1956).

\section{Proline content}

Free proline content was measured by the method given by Bates et al. (1973). Proline contents were calculated in terms of $\mathrm{mg}$ proline/ $\mathrm{gm}$ fresh weight.

\section{Biochemical parameters: Enzymes}

\section{Extraction of enzymes}

All extractions were carried out at $4^{\circ} \mathrm{C}$. The leaves were excised, washed with water and blotted dry. The leaf samples $(1 \mathrm{~g})$ were homogenized with $10 \mathrm{ml}$ of appropriate phosphate buffer like for acid phosphatase phosphate buffer $(0.1 \mathrm{M}, \mathrm{pH}$ 7.0) was used, for invertase acetate buffer (0.2 M, pH-4.8) and for nitrate reductase $0.1 \mathrm{M}$ phosphate buffer having $\mathrm{pH}$ 7.5 was used. The homogenate was extracted at $10,000 \mathrm{xg}$ for 20 minutes. The supernatant thus collected was used for Acid phosphatase (Zink and Veliky, 1979), Invertase (Harris and Jeffcoat, 1974), Nitrate reductase (Jaworski, 1971) assay.

\section{Statistical analysis}

The statistical analysis are the mean values of data of three independent experiments which are performed under same laboratory conditions. One-way analysis of variance (ANOVA) was performed to determine significant differences between mean values of control and each drought-stressed seedling genotype in lentil (Lens culinaris Medik). The variations in the effects of PEG-induced osmotic stress on various physiological and biochemical parameters in eight lentil (Lens culinaris Medik.) genotypes were considered statistically significant at $P<0.05$.

\section{RESULTS AND DISCUSSION}

\section{Biochemical parameters: metabolites}

Changes in certain metabolites were quantitatively determined in the lentil seedlings of different genotypes in response to simulated moisture stress, which lead to the identification of genotypes that are susceptible and tolerant to drought stress. Salient features of such changes in certain metabolites are described below.

\section{Protein content}

The data were analyzed for protein content of lentil Table 1. All the results were found to be significant $(P<0.05)$ at genotypic level. Significant results observed between the genotypes under stress conditions. PL-4 showed significantly higher protein content to the other lentil genotypes. The content of protein was highest $(11.75 \mathrm{mg} / \mathrm{g}$ f. wt.) in PL-4 seedlings followed by L-4147 (9.68 mg/g f. wt.), L-4594 (9.53 mg/g f. wt.) and L-4596 (9.04 mg/g f. wt.). Amongst macrosperma genotypes it was highest $(11.91 \mathrm{mg} /$ g f. wt.) in L-4076 followed by K-75 (10.16 mg/g f. wt.), DPL15 (7.58 mg/g f. wt.) and DPL-62 (7.41 mg/g f. wt.). A general 
Metabolic and Enzymatic Evaluation of Lentil (Lens culinaris M.) Seedlings under Drought Stress

Table 1: Effects of osmopriming on metabolites in eight genotypes of lentil (Lens culinaris Medik.).

\begin{tabular}{|c|c|c|c|c|c|c|c|c|c|}
\hline \multirow{2}{*}{$\begin{array}{l}\text { Genotype } \\
\times \text { stress }\end{array}$} & \multicolumn{3}{|c|}{ Protein content } & \multicolumn{3}{|c|}{ Carbohydrate } & \multicolumn{3}{|c|}{ Proline conten } \\
\hline & NS & WS & $\begin{array}{c}\text { Genotype } \\
\text { mean }\end{array}$ & NS & WS & $\begin{array}{c}\text { Genotype } \\
\text { mean }\end{array}$ & NS & WS & $\begin{array}{c}\text { Genotype } \\
\text { mean }\end{array}$ \\
\hline PL-4 & 11.750 & 10.583 & $11.167 a$ & 9.267 & 21.867 & $15.567 a$ & 0.017 & 0.327 & $0.172 c$ \\
\hline L-4147 & 9.675 & 6.167 & $7.921 b$ & 8.667 & 9.200 & $8.933 d$ & 0.023 & 0.128 & $0.075 d$ \\
\hline L-4594 & 9.525 & 8.750 & $9.138 b$ & 5.333 & 18.000 & $11.667 \mathrm{c}$ & 0.017 & 0.497 & $0.257 b$ \\
\hline L-4596 & 9.042 & 7.583 & $8.313 b$ & 7.867 & 13.467 & $10.667 \mathrm{c}$ & 0.028 & 0.160 & $0.094 d$ \\
\hline $\mathrm{K}-75$ & 10.167 & 5.792 & $7.979 \mathrm{~b}$ & 5.200 & 6.533 & $5.867 d$ & 0.044 & 0.288 & $0.166 \mathrm{c}$ \\
\hline L-4076 & 11.917 & 8.500 & $10.208 a$ & 8.933 & 12.400 & $10.667 c$ & 0.084 & 0.233 & $0.159 c$ \\
\hline DPL-15 & 7.583 & 6.917 & $7.250 \mathrm{c}$ & 10.533 & 23.200 & $16.867 a$ & 0.023 & 0.768 & $0.396 a$ \\
\hline DPL-62 & 7.417 & 5.958 & $6.688 \mathrm{c}$ & 9.067 & 19.200 & $14.133 b$ & 0.051 & 0.373 & $0.212 b$ \\
\hline Stress mean & 9.634 & 7.531 & 8.583 & 8.108 & 15.483 & 11.796 & 0.036 & 0.347 & 0.191 \\
\hline
\end{tabular}

Showing the values at the 0.05 probability, NS $=$ Non stress, WS $=$ Water stress.

Table 2: Effects of osmopriming on enzymes in eight genotypes of lentil (L. culinaris Medik.).

\begin{tabular}{|c|c|c|c|c|c|c|c|c|c|}
\hline \multirow{2}{*}{$\begin{array}{l}\text { Genotype } \\
\times \text { stress }\end{array}$} & \multicolumn{3}{|c|}{ Acid phosphatase } & \multicolumn{3}{|c|}{ Invertase } & \multicolumn{3}{|c|}{ Nitrate reductase (NR) } \\
\hline & NS & WS & $\begin{array}{c}\text { Genotype } \\
\text { mean }\end{array}$ & NS & WS & $\begin{array}{c}\text { Genotype } \\
\text { mean }\end{array}$ & NS & WS & $\begin{array}{c}\text { Genotype } \\
\text { mean }\end{array}$ \\
\hline $\mathrm{PL}-4$ & 5.527 & 4.953 & $5.240 \mathrm{a}$ & 0.067 & 2.313 & $1.460 \mathrm{~b}$ & 48.000 & 46.667 & 47. $333 a$ \\
\hline L-4147 & 4.537 & 4.977 & $4.757 \mathrm{a}$ & 0.669 & 1.490 & $1.080 \mathrm{~b}$ & 56.667 & 31.000 & $43.833 a$ \\
\hline L-4594 & 4.457 & 4.427 & $4.442 \mathrm{a}$ & 0.632 & 2.510 & $1.571 \mathrm{~b}$ & 42.333 & 41.333 & $41.833 a$ \\
\hline L-4595 & 3.560 & 5.017 & $4.288 \mathrm{a}$ & 0.713 & 1.093 & $0.903 \mathrm{~b}$ & 41.333 & 21.000 & $31.167 b$ \\
\hline $\mathrm{K}-75$ & 2.083 & 2.683 & $2.383 \mathrm{~b}$ & 0.777 & 1.587 & $1.182 \mathrm{~b}$ & 26.667 & 15.000 & $20.833 b$ \\
\hline L-4076 & 2.767 & 3.280 & $3.023 \mathrm{~b}$ & 0.715 & 1.353 & $1.034 \mathrm{~b}$ & 52.333 & 29.000 & $40.667 a$ \\
\hline DPL-15 & 4.417 & 4.623 & $4.520 \mathrm{a}$ & 1.238 & 3.697 & $2.468 \mathrm{a}$ & 26.333 & 23.666 & $25.000 b$ \\
\hline DPL-62 & 4.630 & 3.553 & $4.092 \mathrm{a}$ & 0.776 & 3.937 & $2.357 \mathrm{a}$ & 42.333 & 40.667 & $41.500 a$ \\
\hline Stress mean & 3.997 & 4.189 & 4.093 & 0.766 & 2.248 & 1.507 & 42.000 & 31.042 & 36.521 \\
\hline
\end{tabular}

Showing the values at the 0.05 probability, NS $=$ Non stress, WS $=$ Water stress.

decrease in protein content was recorded in all the genotypes by water stress, the reduction was less in drought tolerant and it was more in drought susceptible. Drought stress negatively affects the accumulation of various seed components such as proteins (Asthir et al., 2012; Farooq et al., 2017a,b) by inhibiting the enzymatic processes of synthesis of proteins (Triboï et al., 2003).

\section{Total carbohydrate content}

In general, the level of carbohydrate increased in seedlings subjected to drought stress. Data in Table 1 shows the results and were found to be significant between genotypes and significant variations are also observed between stressed and non-stressed seedlings of genotypes. Drought stress led to significant $(P<0.05)$ increase in carbohydrate content in PL-4 and DPL-15 and increment was significantly more in DPL-15. In response to water stress PL-4 had highest level $(21.86 \mathrm{mg} / \mathrm{g} \mathrm{f}$. wt.) of carbohydrate followed by L-4594 (18.00 mg/g f. wt.), L-4596 (13.46 mg/g f. wt.) and L-4147 ( $9.20 \mathrm{mg} / \mathrm{g} \mathrm{f}$. wt.). Under water stress seedlings of DPL-15 accumulated highest content $(23.2 \mathrm{mg} / \mathrm{g} \mathrm{f}$. wt.) of carbohydrate followed by DPL-62 (19.2 mg/g f. wt.), L-4076 (12.4 mg/g f. wt.) and K-75 (6.53 mg/g f. wt.). Amongst all genotypes DPL-15 showed significantly highest carbohydrate content. Vigna radiata nodules showed a significant increase in sugar content under drought conditions (Hooda et al., 1999). Alfalfa plants also showed an increment in total soluble sugars in leaves and nodules under drought stress conditions (Irigoyen et al., 1992). Soyabean genotypes shown a considerable variation in the sucrose level under drought conditions for example, myoinositol and sucrose levels in the leaves decreased drastically in the sensitive soyabean genotype, but no significant changes were observed in the tolerant genotype (Silvente et al., 2012).

\section{Proline content}

The free proline accumulation showed a common trend of increase in the seedlings under drought stress as depicted in Table 1. A Significant $(P<0.05)$ increment in free proline content was observed in seeds of all genotypes under drought stress. DPL-15 showed significantly highest proline content under drought conditions. The proline content in microsperma subspecies was highest in L-4594 $(0.49 \mathrm{mg} / \mathrm{g}$ f. wt.) followed by PL-4 (0.327 mg/g f. wt.), L-4596 (0.160 $\mathrm{mg} / \mathrm{g} \mathrm{f}$. wt.) and L-4147 (0.128 mg/g f. wt.). Among macrosperma group the proline accumulation was highest (0.768 mg/g f. wt.) in DPL-15 followed by DPL-62 (0.373 
$\mathrm{mg} / \mathrm{g}$ f. wt.), K-75 (0.288 mg/g f. wt.) and L-4076 (0.233 mg/ $\mathrm{g}$ f. wt.). Vigna radiata nodules showed a significant increase in proline content under drought conditions (Hooda et al., 1999). Increase in proline content was reported in alfalfa leaves and nodules under drought stress (Irigoyen et al., 1992). Proline accumulation has been reported under drought stress in different plant species (Ashraf, 2004; Kumar et al., 2017; Awana et al., 2019). PEG induced drought stress in tomato showed 10 -fold increase in proline content (Zgalli et al., 2005).

\section{Biochemical parameters: Enzymes}

\section{Acid phosphatase}

Activity of acid phosphatase was enhanced in response to drought stress in PL-4 (5.52 mM P-nitrophenol) followed by L-4147 (4.53 mM P-nitrophenol), L-4594 (4.45 mM Pnitrophenol) and lowest (3.56 mM P-nitrophenol) in L-4596 genotype of microsperma lentil. The comparative data analysis is shown in Table 2. Contrary to microsperma group the activity of acid phosphatase in macrosperma group was lowered under drought stress and the reduction was highest in L-4076 where acid phosphatase activity was lowest $(2.76$ $\mathrm{mM}$ P-nitrophenol) as compared to control seedlings (3.28 $\mathrm{mM}$ P-nitrophenol). Acid phosphatase activity was increased by salt and drought stress in both cultivars of Medicago sativa explants under in vitro culture and the difference in activities between two genotypes of Medicago sativa indicated that the acid phosphatase activity is highly genotype dependent (Ehsanpour and Amini, 2003). Increased acid phosphatase activity has also been reported in different crop plants under different stresses (Kumar et al., 2021; Sheteiwy et al., 2021).

\section{Invertase}

Simulated water stress also significantly increased invertase activity in seedlings under ambient laboratory conditions shown in Table 2. PEG-6000 treated seedlings of L-4594 recorded the highest $(2.50 \mathrm{mg} / \mathrm{g} \mathrm{f}$. wt.) invertase activity under water stress followed by PL-4 (2.31 mg/g f. wt.), L4147 (1.49 mg/g f. wt.) and L-4596 (1.09 mg/g f. wt.). Amongst macrosperma genotypes DPL-62 showed highest (3.93 $\mathrm{mg} / \mathrm{g} \mathrm{f}$. wt.) invertase activity in the seedlings followed by DPL-15 (3.69 mg/g f. wt.), K-75 (1.58 mg/g f. wt.) and L-4076 (1.35 mg/g f. wt.). The invertase activity was observed to be increased under various biotic and abiotic stress (Roitsch et al., 2003) in maize.

\section{Nitrate reductase (NR)}

There was a general reduction in the activity of nitrate reductase under simulated water stress in seedlings of lentil genotype seedlings, accordingly shown in Table 2. PEG6000 treated seedlings of L-4594 showed the minimum reduction $(2.79 \%)$ it is followed by PL-4 (2.36\%), L-4147 (44.64\%) and L-4596 (49.19\%). Amongst macrosperma genotypes DPL-62 showed minimum reduction (3.94\%) in nitrate reductase activity under simulated water stress followed by DPL-15 (10.14\%), K-75 (43.73\%) and L-4076
$(44.58 \%)$. Our results are in accordance with previous results of water-stress-induced losses in nitrate reductase activity in other species (Wellburn et al.,1996). In tomato also drought observed to decrease the Nitrate Reductase activity (Brewitz et al., 1996). Similar results were observed in leaves of maize (Foyer et al., 1998).

\section{CONCLUSION}

This study found that the seedling growth of PL-4, L-4594, DPL-15, DPL-62 genotypes are highly tolerant to increased level of drought stress. In the present study, seedlings of microsperma and macrosperma sub species showed altered levels of various metabolites and enzymes due to the application of PEG-6000 Solution. PEG-6000 has a high molecular weight. In most of the seed germination experiments it is used to regulate water potential and $P E G$ causes osmotic stress. Earlier studies also found that potentials between -0.4 and $-0.8 / \mathrm{MPa}$ are the best condition for studying seed germination related parameters of different genotypes of plants under drought stress (Khazayi et al., 2008). PEG also used as drought simulator, non-penetrating solution and inert osmotic in germination tests. Osmotic stress obstructs seed germination by reducing water absorption. Drought stress not only inhibited seedling growth in L-4147, L-4596, K-75, L-4076 but also significantly inhibited various metabolites and enzymes. This information can provide a scientific basis for understanding the occurrence of drought resistance in crop plants and provide key information for the management of resistant genotypes amongst all. So, these data are valuable for increasing agricultural production and farmer incomes in drought prone areas. Such kind of studies will be helpful in those areas where most of the time drought conditions prevail in a year. In Rajasthan such drought prone areas are large in numbers and in such areas drought tolerant genotypes may prove better than other drought susceptible genotypes of lentil.

Such kind of studies may lead to an analysis of the drought tolerance potential of seedlings of various crops, that ultimately gives the knowledge about various morphological and biochemical levels that may be treated as drought tolerant trait in the field conditions. In conclusion by observing changes in the metabolites and enzymatic activities drought tolerant genotypes can be obtained in lentil genotypes.

\section{REFERENCES}

Abdellaoui, R., Boughalleb, F., Zayoud, D., Neffati, M., Bakhshandeh, E. (2019). Quantification of Retama raetam seed germination response to temperature and water potential using hydrothermal time concept. Environ Exp Bot. 157: 211-216.

Ashraf, M. (2004). Some important physiological selection criteria for salt tolerance in plants. Flora. 199: 361-376.

Asthir, B., Koundal A., Bains N.S. (2012). Putrescine modulates antioxidant defense response in wheat under high temperature stress. Biol. Plant. 56: 757-761. 
Awana, M., Yadav, K., Rani, K. et al. (2019). Insights into Salt StressInduced Biochemical, Molecular and Epigenetic Regulation of Spatial Responses in Pigeonpea (Cajanus cajan L.). J Plant Growth Regul. 38: 1545-1561. https://doi.org/ 10.1007/s00344-019-09955-4.

Ayyaz, A., Miao, Y., Hannan, F., Islam, F., Zhang, K., Xu, J. et al. (2021). Drought tolerance in Brassica napus is accompanied with enhanced antioxidative protection, photosynthetic and hormonal regulation at seedling stage. Physiologia Plantarum. 172: 1129-1144.

Bano, H., Athar, H.R., Zafar, Z., Kalaji, H.M. and Ashra, M. (2021). Linking changes in chlorophyll a fluorescence with drought stress susceptibility in mung bean [Vigna radiata (L.) Wilczek]. Physiologia Plantarum. 172: 1240-1250.

Bates, L.S., Waldren, R.P. and Teare, I.D. (1973). A rapid determination of free proline for water stress studies. Plant and Soil. 39: 205-207.

Biaecka, B., Ke ${ }^{2}$ pczyn., ski J. (2010). Germination, $\alpha$ and $\alpha$-amylase and total dehydrogenase activities of Amaranthus caudatus seeds under water stress in the presence of ethephon or gibberellin A3. Acta Biel Cracov Ser Bot. 52: 7-12.

Bradford, M.M. (1976). A rapid and sensitive method for the quantitation of microgram quantities of protein utilizing the principle of protein-dye binding. Anal Biochem.72: 248-54.

Brewitz, E., Larsson, C.M., Larsson, M. (1996). Responses of nitrate assimilation and $\mathrm{N}$ translocation in tomato (Lycopersicon esculentum Mill) to reduced ambient air humidity. J. Exp. Bot. 47: 855-861.

Desclaux, D., Huynh, T.T., Roumet, P. (2000). Identification of soybean plant characteristics that indicate the timing of drought stress. Crop Science. 40(3): 716-722.

DuBois, Michel, Gilles, K.A., Hamilton, J.K., Rebers, P.A. and Fred. Smith (1956). Colorimetric Method for Determination of Sugars and Related Substances. Anal. Chem. 28(3): 350-356.

Ehsanpour, A.A. and Amini, F. (2003). Effect of salt and drought stress on acid phosphatase activities in alfalfa (Medicago sativa L.) explants under in vitro culture. African Journal of Biotechnology. 2(5): 133-135.

Farooq M., Gogoi, N., Barthakur S., Baroowa B., Bharadwaj N., Alghamdi S.S., et al. (2017a). Drought stress in grain legumes during reproduction and grain filling. J. Agron. Crop Sci. 203: 81-102. 10.1093/jxb/err139.

Farooq, M., Nadeem, F., Gogoi, N., Ullah, A., Alghamdi, S.S., Nayyar, $\mathrm{H}$., et al. (2017b). Heat stress in grain legumes during reproductive and grain-filling phases. Crop Pasture Sci. 68: 985-1005. 10.1071/CP17012.

Forcella, F., Arnold, R.L.B., Sanchez, R., Ghersa, C.M. (2000). Modeling seedling emergence. Field Crops Res. 67: 123-139.

Foyer, C.H., Marie-He ile 'ne Valadier andrea Migge and Thomas, W. Becke. (1998). Drought-induced effects on nitrate reductase activity and mRNA and on the coordination of nitrogen and carbon metabolism in maize leaves. Plant Physiol. 117: 283-292.

Gul, F., Ahmed, I., Ashfaq, M., Jan, D., Fahad, S., Wang, X. Li, D., Fhad, M., Fayyaz, M., Shah, S.A. (2020). Use of crop growth model to stimulate the impact of climate change on yield of various wheat cultivars under different agro- environmental conditions in Khyber Pakhtunkhwa, Pakistan. Arab. J. Geosci. 13: 112. 10.1007/s12517-0205118-1.

Harris, G.P., Jeffcoat, B. (1974). Effects of temperature on the distribution of ${ }^{14} \mathrm{C}$-labelled assimilates in the flowering shoot of carnation. Ann. Bot. 38. 77-83.

Hohl, M. and P. Schopfer. (1991). Water relations of growing maize coleoptiles. Comparison between mannitol and Polyethylene glycol 6000 as external osmotic for adjusting turgor pressure. Plant Physiol. 95: 716-722.

Hooda, P.S., Moynagh, M., Svoboda, I.F., Edwards, A.C. anderson, H.A., Sym, G. (1999). Phosphorus loss in drain flow from intensively managed grassland soils. J. Environ. Qual. 28: $1235-1242$.

IPCC. (2007). Climate Change 2007: Synthesis Report, Contribution of Working Groups I, II and III to the Fourth Assessment Report of the Intergovernmental Panel on Climate Change. In: Pachauri, R.K., Reisinger, A., editors. Core Writing Team. Geneva: IPCC. 104 p.

Irigoyen, J.J., Einerich, D.W., Sanchez-Diaz, M. (1992). Water stress induced changes in concentrations of proline and total soluble sugars in nodulated alfalfa (Medicago sativa) plants. Physiologia Plantarum. 84(1): 55-60.

Jaworski, E. (1971). Nitrate reductase assay in intact plant tissues. Biochem. Biophys. Res. Commun. 43: 1247-1279.

Kaya, M.D., Okcu, G., Atak, M., Cıkıhı, Y., Kolsarıcı, O. (2006). Seed treatments to overcome salt and drought stress during germination in sunflower (Helianthus annuus L.). European Journal of Agronomy. 24(4): 291-295.

Khazayi, H. and Kafi, M. (2008). Physiological effects of stress induced by polyethylene glycol on germination of chickpea genotypes. J. Agron Research Iran. 2(6): p-453

Khourgami, A., Maghooli, E., Rafiee, M., Bitarafan, Z. (2012). Lentil response to supplementary irrigation and plant density under dry farming condition. Int. J. Sci. Adv. Technol. 2: 51-55.

Kumar, S., Beena, A.S., Awana, M. and Singh, A. (2017). Physiological, biochemical, epigenetic and molecular analyses of wheat (Triticum aestivum) genotypes with contrasting salt tolerance. Front. Plant Sci. 8: 1151. doi: 10.3389/ fpls.2017.01151.

Kumar, S., Pallavi, Chugh, C. et al. (2021). Characterization of contrasting rice (Oryza sativa L.) genotypes reveals the $\mathrm{Pi}$-efficient schema for phosphate starvation tolerance. BMC Plant Biol. 21. 282. https://doi.org/10.1186/s12870021-03015-4.

Li, Haiyan, Xiaoshuang Li, Daoyuan Zhang, Huiliang Liu, Kaiyun Guan. (2013). Effects of drought stress on the seed germination and early seedling growth of the endemic desert plant Eremosparton Songoricum (Fabaceae). EXCLI Journal 2013. (12): 89-101- ISSN 1611-2156.

Muscolo, A., Sidari, M., Anastasi, U., Santonoceto, C., Maggio, A. (2014). Effect of PEG-induced drought stress on seed germination of four lentil genotypes. Journal of Plant Interactions. 9: 354-363. [CrossRef].

Okcu Gamze, Mehmet Demir Kaya, Mehmet Atak. (2005). Effects of salt and drought stresses on germination and seedling growth of pea (Pisum sativum L.). Turk. J. Agric. For. (29): 237-242. 
Ranjbarfordoei, A., Samson, R., Van Damme, P., Lemeur, R. (2000). Effects of drought stress induced by polyethylene glycol on pigment content and photosynthetic gas exchange of Pistacia Khinjuk and P. mutica. Photosynthetica. 38: 443-447. [CrossRef]

Roitsch, T., Balibrea, M.E., Hofmann, M., Proels, R., Sinha, A.K. (2003). Extracellular invertase: key metabolic enzyme and PR protein. Journal of Experimental Botany. 54(382): 513-524.

Salehi, M., Haghnazari, A., Shekari, F. and Faramarzi, A. (2008). The study of seed yield and seed yield components of lentil (Lens culinaris Medik) under normal and drought stress conditions. Pak. J. Biol. Sci. 11: 758-62.

Sheteiwy, M.S., Dina, F.I.A., You-Cai, X., Marian, B., Milan, S., Yousef, A.H., Zaid, U., Hiba, S., Hamada A.E., Farooq, M., Sharma, A. and El-Sawah, A.M. (2021). Physiological and biochemical responses of soybean plants inoculated with Arbuscular mycorrhizal fungi and Bradyrhizobium under drought stress. BMC Plant Biology. 21: 195.

Silvente, S., Sobolev, A.P. and Lara, M. (2012). Metabolite adjustments in drought tolerant and sensitive soybean genotypes in response to water stress. PLoS ONE. 7: e38554. doi: 10.1371/journal.pone.0038554.
Triboï, E., Martre, P., Triboï-Blondel, A.M. (2003). Environmentallyinduced changes of protein composition for developing grains of wheat are related to changes in total protein content. J. Exp. Bot. 54: 1731-1742. 10.1093/jxb/erg183.

Wellburn, F.A.M., Lau, K.K, Milling, P.M.K., Wellburn, A.R. (1996). Drought and air pollution affect nitrogen cycling and free radical scavenging in Pinus halepensis (Mill). J. Exp. Bot. 47: 1361-1367.

Xiong, R., Liu, S., Considine, M. J., Siddique, K.H.M., Lam, H.M. and Chen, Y. (2020). Root system architecture, physiological and transcriptional traits of soybean (Glycine max L.) in response to water deficit: A review. Physiologia Plantarum. 172: 405-418.

Zgallai, H., Steppe, K. and Lemeur, R. (2005). Photosynthetic, physiological and biochemical responses of tomato plants to polyethylene glycol-induced water deficit. J. Integr. Plant Biol. 47(12): 1470-1478.

Zink, M.W. and Veliky, I.A. (1979). Acid phosphatase of Ipomoea $\mathrm{Sp}$. Cultured in vitro $\mathrm{L}$. influence of $\mathrm{pH}$ and inorganic phosphate on the formation of phosphatases. Can. J. Bot. 57: 739-753.

Zohary, D. (1972). The wild progenitor and place of origin of the cultivated lentil Lens culinaris. Econ Bot. 26: 326-332. 